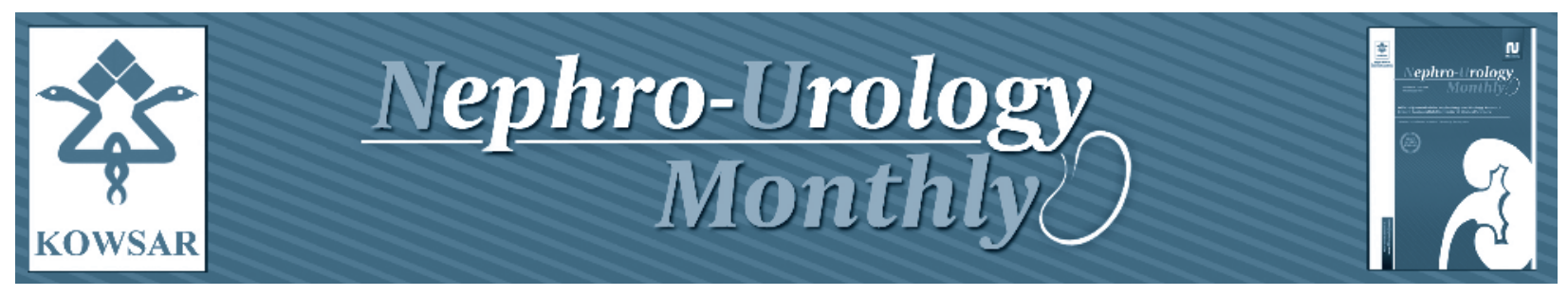

\title{
Smoking and Chronic Kidney Disease in Healthy Populations
}

\author{
Yuka Noborisaka ${ }^{1^{*}}$ \\ ${ }^{1}$ Department of Social and Environmental Medicine, School of Medicine, Kanazawa Medical University, Ishikawa, Japan \\ * Corresponding author: Yuka Noborisaka, Department of Social and Environmental Medicine, School of Medicine, Kanazawa Medical University, 1-1 Uchi- \\ nada, Ishikawa, Japan. Tel.: +76-2188101, Fax: +76-2869723, E-mail: hygiene@kanazawa-med.ac.jp
}

\begin{abstract}
A B S T R A C T
The objective of this review is to explore the link between smoking and the development of chronic kidney disease (CKD) in generally healthy populations without pre-existing renal dysfunction such as diabetic nephropathy. Twenty-eight epidemiological studies concerning the renal effects of smoking in the general population were collected from the MEDLINE database and were reviewed for indications of proteinuria and/or the decline of glomerular filtration rate (GFR), and evaluated on the level of evidence and the quality of the study. Sixteen of the 28 studies were cross-sectional in design. Most articles had some weakness in scope, such as the 6 articles which did not fully exclude DM patients from the subjects, the 4 that did not consider the effects of ex-smoking, and the 3 that focused on only a small number of subjects. From these cases, it is difficult to draw firm conclusions. However, proteinuria or microalbuminuria was persistently high in current smokers; as much as 5-8\% or 8-15\% respectively, which was up to 2 to 3 -times the rate of lifelong non-smokers. On the other hand, only 5 studies broader in scope detected any decline of GFR in smokers, while 9 other studies suggested a higher GFR in smokers than in non-smokers. Two good quality studies showed an even a significantly lower risk of a decreased GFR in smokers. These paradoxical CKD markers in smokers, i.e., a higher appearance of proteinuria with a higher GFR, could be a focus for further studies to reveal the underlying reasons for smoking-induced CKD. Workplaces may be an excellent place to study this subject since the long-term changes in renal function of smokers can be observed by collecting data in the annual health check-ups mandated at places of employment.
\end{abstract}

Keywords: Smoking; Kidney Failure, Chronic; Proteinuria; Glomerular Filtration Rete

\section{Background}

The adverse renal effects of smoking were first demonstrated in patients with diabetes mellitus, and successively in those with primary kidney disease such as polycystic kidney, glomerulonephritis and lupus nephritis, and those with primary hypertension (1-4). An epoch-making report published in 2000 by the PREVEND (prevention of REnal and vascular ENd stage disease) study group (5) showed that smoking was associated with an excessive urinary albumin excretion in inhabitants without diabetes in a Dutch community. This study suggested that smoking induces chronic kidney disease (CKD) as manifested by proteinuria and/or lowered glomerular filtration rate (GFR) even in generally healthy adults.

In 2007, Jones-Burton et al. (6) reviewed 17 articles

Article type: Review Article; Received: 14 Nov 2011, Revised: 08 Dec 2011, Accepted: 09 Jan 2012; DOI: 10.5812/numonthly.3527

Implication for health policy/practice/research/medical education:

Many previous studies in healthy populations showed a higher appearance of proteinuria with a higher GFR in smokers, and the underlying reasons for the paradoxical markers of CKD in smokers could be a focus for further studies.

-Please cite this paper as:

Noborisaka Y. Smoking and Chronic Kidney Disease (CKD) in Healthy Populations. Nephro-Urol Mon. 2013;5(1): 655-667. DOI:10.5812/ numonthly.3527

Copyright (C) 2013, Kowsar Corp;; Published by Kowsar Corp.

This is an Open Access article distributed under the terms of the Creative Commons Attribution License (http://creativecommons.org/licenses/by/3.0), which permits unrestricted use, distribution, and reproduction in any medium, provided the original work is properly cited. 
concerning the association of cigarette smoking with the incidence of CKD and concluded that smoking is a significant risk factor for CKD, but that the depth of the correlation remains obscure due to the vast heterogeneity in the source populations and in the methods used to measure the outcomes. Furthermore, most of the studies included a considerable number of subjects who were diabetic. Since the renal effects of smoking are more wellknown in patients with diabetic nephropathy, the impact of smoking in healthy adults without that renal dysfunction is even more difficult to determine. We tried to elucidate, therefore, the possible association between chronic smoking and CKD in generally healthy populations by reviewing previous studies conducted on this matter.

\section{Review of the Literature}

The literature concerning the renal effects of cigarette smoking in generally healthy populations was researched on the MEDLINE database using a PubMed interface on April 8, 2011. All articles published in English from 1966 onwards were searched using the following combination of terms: smoking AND (proteinuria OR albuminuria OR kidney diseases). 2,881 articles were retrieved in this manner. According to the titles, and abstracts if available, 51 original articles describing epidemiological studies conducted in the general population regarding the prevalence and incidence of the signs of CKD were selected and examined in the full length papers. Excluding duplicated articles, or those conducted mainly on diseased patients, or those not noting CKD with regards to smoking, or those not considering the effects of confounding factors, and including two recently published articles of our own (7), 28 articles were reviewed. All papers were evaluated for the level of evidence (LOE) according to the criteria proposed by the Agency for Health Care Policy and Research (AHCRP) in 1993, and for the quality of study based on items selected from the recommendations for good analytical epidemiological studies $(8,9)$.

The items are shown in Table $1: 1)$ the selection of subjects, for the definition in accordance with the goal of this review and the appropriateness of the mother population, 2) the size of the study population, 3) the duration of observation in cohort studies, 4) the definition of exposure (smoking status in this review), 5) the measurement of outcome (proteinuria and renal function), 6) statistical analyses, and 7) considerations of confounding factors. Each item was graded as "good", "fair", or "acceptable" where appropriate.

Table 1. Items and Grades for Quality Evaluation of the Analytical Epidemiological Studies on the Smoking-Induced Renal Damage in the Generally Healthy Population

\begin{tabular}{|c|c|c|c|}
\hline \multicolumn{4}{|c|}{ Grades } \\
\hline Items & Good & Fair & Acceptable \\
\hline \multicolumn{4}{|l|}{ Selection of subjects } \\
\hline Definition $^{\mathrm{a}}$ & $\begin{array}{l}\text { Recruited from community } \\
\text { or workplace with exclusion } \\
\text { of preceding primary kidney } \\
\text { diseases and DM }\end{array}$ & $\begin{array}{l}\text { Recruited from community } \\
\text { or workplace with exclusion } \\
\text { of preceding primary kidney } \\
\text { diseases }\end{array}$ & $\begin{array}{l}\text { Recruited from community or } \\
\text { workplace without any exclu- } \\
\text { sion of preceding diseases }\end{array}$ \\
\hline Representativeness & $\begin{array}{l}\text { Randomized selection from or } \\
\text { including } 70 \% \text { or more of the } \\
\text { whole population }\end{array}$ & $\begin{array}{l}\text { Not randomized but not arbi- } \\
\text { trary selection from the whole } \\
\text { population }\end{array}$ & \\
\hline Size of population & $\begin{array}{l}4,000 \text { or more in men and } \\
8,000 \text { or more in women }\end{array}$ & $\begin{array}{l}400 \text { or more in men and } 800 \\
\text { or more in womenb }\end{array}$ & $\begin{array}{l}100 \text { or more in men and } 200 \\
\text { or more in women }\end{array}$ \\
\hline Duration of observation ${ }^{C}$ & 10 years or longer & 5 years or longer & 2 years or longer \\
\hline $\begin{array}{l}\text { Definition of } \\
\text { exposure(Smoking status) }\end{array}$ & $\begin{array}{l}\text { Smoker / Exsmoker Never } \\
\text { smoker Accumulated dose }\end{array}$ & $\begin{array}{l}\text { Smoker / Exsmoker Never } \\
\text { smoker }\end{array}$ & Smoker/non-smoker \\
\hline \multicolumn{4}{|l|}{ Measurement of outcome } \\
\hline $\begin{array}{l}\text { Proteinuria (Albumin- } \\
\text { uria) }\end{array}$ & Quantitative measurement & $\begin{array}{l}\text { Semiquantitative (dipstick) } \\
\text { measurement }\end{array}$ & \\
\hline Renal function & $\begin{array}{l}\text { Actual measurement of GFR or } \\
\text { Ccr or Estimation of GFR by a } \\
\text { standardized equation }\end{array}$ & $\begin{array}{l}\text { Estimation of Ccr by a Cock- } \\
\text { croftGault Equation or Mea- } \\
\text { surement of serum creatinine } \\
\text { concentration }\end{array}$ & \\
\hline Statistical analysis & $\begin{array}{l}\text { Appropriate methods, Appro- } \\
\text { priate description }\end{array}$ & Appropriate methods & \\
\hline
\end{tabular}




\section{Consideration on confound- $\quad$ Demographic factors, Anthro- ing factors $\mathrm{d}$ pometrical factors, Impaired Demographic factors, Anthro- $\quad$ Demographic factors pometrical factors \\ GT and high BP}

Abbreviations: BP, blood pressure; Ccr, creatinine clearance CKD, chronic kidney disease; DM, diabetes mellitus; GFR, glomerular filtration rate; GT, glucose tolerance.

a In cohort study, the patients with the endpoint CKD should be excluded at the baseline.

$\mathrm{b}$ Minimal ample size required to detect the difference in the prevalence of CKD between smokers and nonsmokers.

${ }^{c}$ Required item in cohort study.

$\mathrm{d}$ Appropriate matching of case and control or applying appropriate multivariate analyses.

The study subjects should be generally healthy for this review, and thus the exclusion of subjects who may have pre-existing renal dysfunction, especially those due to primary kidney diseases or diabetes mellitus, is required for a "good" study. At least, the subjects should be recruited from communities or workplaces even though those exclusions were not fully completed as shown in "acceptable". Appropriateness is graded as "good" when the participating subjects were randomly collected from the mother population or consisted of $70 \%$ or more of the population. Non-arbitrary collection of the subjects such as volunteers for health screenings is graded as "fair".

Assuming the prevalence of proteinuria to be $5 \%$ in smokers and $3 \%$ in non-smokers, and the smoking rate to be $30 \%$ of male and $15 \%$ of female subjects, the minimum sample size required to detect a significant difference is estimated to be 400 in men and 800 in women, which is graded as "fair". A sample size that is ten times larger

Table 2. The Effects of Smoking on Proteinuria or Albuminuria in Healthy Populations

\begin{tabular}{|c|c|c|c|c|}
\hline Authors & Year & Study Design (LOE) & Main Outcomes & Quality $^{\mathrm{a}} /$ Comment $^{\mathrm{b}}$ \\
\hline Metcalf PA,et al.(19) & 1993 & $\begin{array}{l}\text { Cross-sectional in 5,670 } \\
\text { people aged } 40-78 \text { years } \\
\text { in a community of New } \\
\text { Zealand(III) }\end{array}$ & $\begin{array}{l}\text { Mantel-Haenszel OR for } \\
\text { slight albuminuria (29- } \\
299 \mathrm{mg} / \mathrm{l} \text { in men and } \\
30-299 \mathrm{mg} / \mathrm{l} \text { in women) } \\
\text { in current smokers vs. } \\
\text { never smokers was } 1.37 \\
\text { (1.01 1.88) adjusted for } \\
\text { age, gender, ethnicity, }\end{array}$ & $\begin{array}{l}\text { B/ Not excluding DM } \\
\text { patients }\end{array}$ \\
\hline
\end{tabular}

\begin{tabular}{|c|c|c|c|c|}
\hline \multirow[b]{2}{*}{ Goetz FC,et al.(14) } & \multirow[b]{2}{*}{1997} & \multirow[b]{2}{*}{$\begin{array}{l}\text { 5-yr follow up in } 455 \\
\text { adults in a U.S. commu- } \\
\text { nity }\left(\mathrm{II}^{\mathrm{a}}\right)\end{array}$} & \\
\hline & & & $\begin{array}{l}\text { Prevalence of in- } \\
\text { creased urinary } \\
\text { albumin( } \geq 15 \mu \mathrm{g} / \mathrm{min}) \\
\text { was twofold more } \\
\text { frequent in current } \\
\text { smokers (13\%) than in } \\
\text { ex- and never smokers } \\
\text { ( } 7 \% \text { ) at the baseline } \\
\text { measurement adjusted } \\
\text { for age, gender, BMI and } \\
\text { DM, but this difference } \\
\text { was not significant. }\end{array}$ & $\begin{array}{l}\text { C/Small number of } \\
\text { subjects }\end{array}$ \\
\hline Cirillo M,et al.(13) & 1998 & $\begin{array}{l}\text { Cross-sectional in } 677 \\
\text { men and } 890 \text { women in } \\
\text { an Italian community } \\
\text { (III) }\end{array}$ & $\begin{array}{l}\text { Number of cigarettes } \\
\text { consumed per day } \\
\text { was correlated with } \\
\text { overnight urinary } \\
\text { albumin excretion } \\
\text { adjusted for age, BMI } \\
\text { and alcohol OR for } \\
\text { microalbuminuria ( } 20 \text { - } \\
199 \mu \text { g/min) in male and } \\
\text { female current smokers } \\
\text { vs. non-smokers was } \\
1.99 \text { (0.97 4.07) and } 1.91 \\
\text { (0.73 4.96) respectively } \\
\text { adjusted for the con- } \\
\text { founders. }\end{array}$ & $\begin{array}{l}\text { C/Ex-smoking was not } \\
\text { considered }\end{array}$ \\
\hline
\end{tabular}




\begin{tabular}{|c|c|c|c|c|}
\hline $\begin{array}{l}\text { Pinto-Sietsma SJ,et } \\
\text { al.(21) }\end{array}$ & 2000 & $\begin{array}{l}\text { Cross-sectional in 7,476 } \\
\text { adults in a Dutch com- } \\
\text { munity (III) }\end{array}$ & $\begin{array}{l}\text { OR for microalbumin- } \\
\text { uria ( } 30-300 \mathrm{mg} / 24 \mathrm{~h} \text { ) } \\
\text { in current smokers } \\
\text { consuming up to } 20 \\
\text { cigarettes per day and } \\
\text { in those consuming } \\
\text { more vs. never smokers } \\
\text { was } 1.92 \text { (1.54 2.39) and } \\
2.15(1.52 \sim 3.03) \text { respec- } \\
\text { tively adjusted for age, } \\
\text { gender, BMI, BP, FPG and } \\
\text { alcohol. }\end{array}$ & A \\
\hline Halimi JM, et al.(15) & 2000 & $\begin{array}{l}\text { Cross-sectional in } \\
28,409 \text { French partici- } \\
\text { pants in a health screen- } \\
\text { ing (III) }\end{array}$ & $\begin{array}{l}\text { OR for proteinuria } \\
\text { (dipstick) was } 2.03 \\
(1.43 \sim 2.93) \text { in normo- } \\
\text { tensive current smokers } \\
\text { and } 2.36(1.14 \sim 5.32) \text { in } \\
\text { hypertensive smok- } \\
\text { ers vs. nonsmokers } \\
\text { adjusted for age, gender } \\
\text { and BP. }\end{array}$ & $\begin{array}{l}\text { B/Dipstick for protein- } \\
\text { uria }\end{array}$ \\
\hline Tozawa $\mathbf{M}$,et al.(23) & 2002 & $\begin{array}{l}\text { 22-yr follow-up in 3,403 } \\
\text { male and 2,000 female } \\
\text { Japanese participants in } \\
\text { health screening }\left(\mathrm{II}^{\mathrm{a}}\right)\end{array}$ & $\begin{array}{l}\text { OR for incident protein- } \\
\text { uria (dipstick) in male } \\
\text { and female current } \\
\text { smokers vs. nonsmok- } \\
\text { ers was1.28 }(0.96 \sim 1.72) \\
\text { and } 1.30(0.44 \sim 3.80) \\
\text { respectively adjusted } \\
\text { for age, obesity, hyper- } \\
\text { tension and DM. }\end{array}$ & $\begin{array}{l}\text { C/Short period of obser- } \\
\text { vation }\end{array}$ \\
\hline Briganti EM,et al.(12) & 2002 & $\begin{array}{l}\text { Population-based Case- } \\
\text { control study in } 11,247 \\
\text { adults in an Australian } \\
\text { community(III) }\end{array}$ & $\begin{array}{l}\text { OR for proteinuria } \\
\text { ( } \geq 0.2 \mathrm{mg} / \mathrm{mg} . \mathrm{Cr}) \text { in } \\
\text { current smokers was } \\
1.58(0.53 \sim 4.75) \text {, not } \\
\text { significant, but it was } \\
\text { significant, } 3.64 \text { when } \\
\text { SBP of } 131.5 \mathrm{mmHg} \text { or } \\
\text { higher or, } 1.76 \text { when } 2-\mathrm{h} \\
\text { post-loaded glucose was } \\
126 \mathrm{mg} / \mathrm{dl} \text { or above. }\end{array}$ & $\begin{array}{l}\text { C/ Ex-smoking was not } \\
\text { considered }\end{array}$ \\
\hline Yamada Y,et al.(24) & 2004 & $\begin{array}{l}\text { Cross-sectional in } 11,569 \\
\text { male and } 4,715 \text { female } \\
\text { Japanese workers(III) }\end{array}$ & $\begin{array}{l}\text { OR for proteinuria } \\
\text { (dipstick) was } 1.11 \\
(1.15 \sim 1.63) \text { at each } \\
\text { level of BI }(0,1 ; B I: 1-199 \text {, } \\
\text { 2;BI:200-499,3;BI:500- } \\
799,4 ; \text { BI:800-) adjusted } \\
\text { for age, gender, DM and } \\
\text { BP. OR for proteinuria } \\
\text { in smokers aged } 50 \\
\text { years or older with a } \\
\text { BI of } 500 \text { or above and } \\
\text { a normal high BP was } \\
5.44(2.27 \sim 13.0) \text {. }\end{array}$ & $\begin{array}{l}\text { B/Dipstick for protein- } \\
\text { uria }\end{array}$ \\
\hline
\end{tabular}




\begin{tabular}{|c|c|c|}
\hline Hogan SL, et al.(16) & 2007 & $\begin{array}{l}\text { Cross-sectional in } 15,169 \\
\text { adults from U.S. com- } \\
\text { munities (III) }\end{array}$ \\
\hline Zhang L, et al.(26) & 2008 & $\begin{array}{l}\text { Cross-sectional in } 13,925 \\
\text { adults in communities } \\
\text { in China(III) }\end{array}$ \\
\hline Ishizaka $\mathbf{N}$,et al.(17) & 2008 & $\begin{array}{l}\text { Cross-sectional in } \\
7,078 \text { Japanese male } \\
\text { participants in health } \\
\text { screening (III) }\end{array}$ \\
\hline
\end{tabular}

\begin{tabular}{|ll} 
Yoon HJ,et al.(25) $\quad 2009$ & \\
& $\begin{array}{l}\text { Cross-sectional in 35,228 } \\
\text { Korean participants in } \\
\text { health screening (III) }\end{array}$ \\
& \\
\hline Krol E,et al.(18) & \\
& \\
& $\begin{array}{l}\text { Cross-sectional in 2,469 } \\
\text { Polish adults in a com- } \\
\text { munity (III) }\end{array}$
\end{tabular}

O'Seaghdha CM,et 2010
al.(20)
In hypertensive subjects, OR for albuminuria ( $\geq 17 \mu \mathrm{g} / \mathrm{mg}$.Cr in men and $\geq 25 \mu \mathrm{g} / \mathrm{mg}$.Cr in women) was 1.85 (1.29 2.64) in current smokers vs. never smokers adjusted for age, gender. No significant effects of smoking were found in normotensive subjects.

OR for albuminuria ( $\geq$ $17 \mu \mathrm{g} / \mathrm{mg}$.Cr in men and $\geq 25 \mu \mathrm{g} / \mathrm{mg}$. Cr in women) was 0.94 (0.78 1.13) in current smokers vs. nonsmokers adjusted for age, gender, obesity, DM, hyper tension and hyperlipidemia.

OR for albuminuria ( $\geq$ $30 \mathrm{mg} / \mathrm{g}$.Cr) in current smokers consuming 20-39 cigarettes per day and those consuming more was 1.56 (1.17 2.08) and 1.88 (0.99 3.55) respectively in comparison with never smokers adjusted for age, BP and FPG.

\section{OR for proteinuria} (dipstick) in current smokers consuming more than 20 cigarettes per day or more vs. nonsmokers was $1.33(1.09 \sim 1.64)$ in men and $1.89(0.91 \sim 3.87)$ in women adjusted for age, BMI, BP, FPG.

\section{OR for albuminuria} (a dipstick) in male current smokers vs. nonsmokers was 1.58 (1.07 2.33)adjusted for age, BMI, DM and hypertension, but not significant in female subjects.

\section{OR for albuminuria ( $\geq$} $17 \mu \mathrm{g} / \mathrm{mg}$.Cr in men and $\geq 25 \mu \mathrm{g} / \mathrm{mg}$.Cr in women) in current smokers vs. nonsmokers was 2.09 (1.36 3.22) adjusted for age, gender, DM and baseline urinary albumin.
B/ Not excluding DM

patients

B/ Ex-smoking was not considered

\section{B/ Not excluding DM}

patients

\section{B/ Dipstick for albumin-} uria

B/ Not-randomized selection of the subjects

b/ Not-randomized selection of the the subjects inhabitants in a U.S. community(II $\left.{ }^{a}\right)$ 
Sauriasari R,et al.(22) 2010
Cross-sectional in 290 male and 359 female Japanese participants in health screening (III)

Noborisaka Y,et al.(7) $\quad 2011 \quad \begin{aligned} & \text { Cross-sectional in } 990 \\ & \text { middle-aged Japanese } \\ & \text { men from a chemical } \\ & \text { plant (III) }\end{aligned}$

OR for proteinuria

( $\geq 49.4 \mathrm{mg} / \mathrm{g}$.Cr) in smokers consuming 20 pack-years or more vs. never smokers was 1.56 (0.79 3.09) adjusted for age, gender, BMI and BP.

$\begin{aligned} & \text { OR for proteinuria (a } \\ & \text { dipstick) in men who }\end{aligned}$
have a BI of $400-599$
and those have a BI
of 600 or higher was
2.94(1.01 8.55) and
3.61(1.29 10.1), respec-
tively, adjusted for age,
BMI, high BP, high FPG
and high serum lipids.

C/Small number of subjects

Abbreviations: BI, Brinkman Index, BMI, body mass index, BP, blood pressure; Cr, creatinine; DM, diabetes mellitus;.FPG, fasting plasma glucose; LOE, level of evidence defined by AHCPR (1993); OR, odds ratio

a Quality: For the definition, refer to text and Table 1.

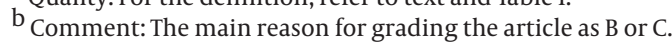

is graded as "good", and the sample size of 100 men and 200 women or more is graded as "acceptable". For the range of the study (smoking in this review), the effects of past smoking should be considered, and thus the studies classifying the subjects only into current smokers or nonsmokers are graded low as "acceptable". For the measurements of proteinuria or albuminuria as the outcome, quantitative measurements of these parameters in urine are graded as "good", and semi-quantitative measurements using a dipstick are graded as "fair". For renal function, using a well standardized equation for estimating GFR, such as that proposed by the modification of diet in renal disease (MDRD) study group (10), or by the Japan Society of Nephrology (JSN) is graded as "good" as well as the actual measurement of GFR or creatinine clearance (Ccr). Ccr estimated by the Cockcroft and Gault (CG) equation (11) or simply serum creatinine (Cr) concentration for the index of renal function is graded as "fair" because of the lower validity for estimating real GFR values. Confounding factors should be matched or adjusted for using a multivariate analysis, and consideration of demographic factors is required for "acceptable". As a final point ," the articles which are graded as "good" in all the items are classified as "A", those graded as "acceptable" in any of the items are classified as " $\mathrm{C}$ ", and the remaining are classified as "B". Sixteen of the 28 articles reported the effects of smoking on proteinuria or albuminuria $(7,12-$ $26)$, and 21 reported the effects on renal function $(7,12,14$, $15,17,21,22,25-38)$.

\section{Proteinuria or Albuminuria in Smokers}

As revealed in Table 2,13 of the 16 studies on proteinuria or albuminuria were cross-sectional in design (LOE of 3 ). Only one study was classified as "A" in the quality and 9 were classified as "B" because of the use of a dipstick method for detecting proteinuria (3 articles) or albuminuria ( 1 article), not fully excluding DM patients from the subjects (3 articles), or not-randomized selection of the subjects ( 2 articles). Six studies were classified as "C": 3 articles because of not considering ex-smoking, 2 because of the small number of subjects and one cohort study because of the short period of observation.

Therefore, firm conclusions cannot to be drawn from those studies, but the following has been observed: 1 ) proteinuria or microalbuminuria was found in $5-8 \%(7,23$, $24)$ or $8-15 \%(14,17,21,25)$ respectively, of current smokers being generally higher than in non-smokers, with up to 2 to 3-times higher than the rate of lifelong non-smokers, and 2) smoking-induced proteinuria is detectable even in middle-aged persons from the working populations $(7,17$, $22,24,25)$, but 3 ) it is found more frequently in those with a higher BP $(12,24)$, higher blood glucose (12) and a higher age of 50 years or older (24).

\section{Renal Function in Smokers}

As shown in Table 3,10 of the 21 studies on renal function are follow-up designs (LOE of 2). Three studies were classified as " $\mathrm{A}$ " for the quality and 9 were classified as "B" because DM patients were not fully excluded (5 articles) or outcomes measured by the Ccr by the CG equation or serum $\mathrm{Cr}$ concentration (4 articles). Including 6 followup studies, 9 articles were classified as "C": 3 articles because of the small number of the subjects, 3 because of not considering ex-smoking, 2 because of not excluding mild CKD patients in the follow-up studies in which renal failure was set as the endpoint, and 1 because of short period of the observation.

The overall outcomes in the studies on renal function are conflicting. Only 5 studies with grade A or B in qual- 
Table 3. The Effects of Smoking on Renal Function in Healthy Populations

\begin{tabular}{|c|c|c|c|c|}
\hline Authors & Year & Study Design (LOE) & Main Outcomes & Quality $^{\mathrm{a}}$ / Comment ${ }^{\mathrm{b}}$ \\
\hline Goetz FC,et al.(14) & 1997 & $\begin{array}{l}\text { 5-yr follow up in } 455 \\
\text { adults in a U.S. commu- } \\
\text { nity }\left(\mathrm{II}^{\mathrm{a}}\right)\end{array}$ & $\begin{array}{l}\text { Mean Ccr was signifi- } \\
\text { cantly higher in current } \\
\text { smokers than in ex-and } \\
\text { never smokers adjusted } \\
\text { for age, gender, BMI, } \\
\text { BP and DM. Decline of } \\
\text { Ccr during } 5 \text { years was } \\
\text { significantly greater in } \\
\text { current and ex-smokers } \\
\text { than in never smokers } \\
\text { adjusted for the con- } \\
\text { founders. }\end{array}$ & $\begin{array}{l}\text { c/Small number of } \\
\text { subjects }\end{array}$ \\
\hline
\end{tabular}

\begin{tabular}{|c|c|c|c|c|}
\hline $\begin{array}{l}\text { Pinto-Sietsma SJ,et } \\
\text { al.(21) }\end{array}$ & 2000 & $\begin{array}{l}\text { Cross-sectional in 7,476 } \\
\text { adults in a Dutch com- } \\
\text { munity (III) }\end{array}$ & $\begin{array}{l}\text { OR for elevated eGFR } \\
\text { (>Mean+2SD) in current } \\
\text { smokers consuming up } \\
\text { to } 20 \text { cigarettes per day } \\
\text { and in those consuming } \\
\text { more vs. never smok- } \\
\text { ers was } 1.82(1.31 \sim 2.53) \\
\text { and } 1.84(1.12 \sim 3.02) \\
\text { respectively adjusted } \\
\text { for age, gender, BMI, } \\
\text { BP, PG and alcohol. OR } \\
\text { for decreased eGFR } \\
\text { (<Mean-2SD) in current } \\
\text { smokers consuming up } \\
\text { to } 20 \text { cigarettes per day } \\
\text { and in those consuming } \\
\text { more vs. never smokers } \\
\text { was } 1.53 \text { (1.04 2.24) and } \\
1.83 \text { (1.05 3.20) respec- } \\
\text { tively adjusted for the } \\
\text { confounders. }\end{array}$ & A \\
\hline Halimi JM,et al.(15) & 2000 & $\begin{array}{l}\text { Cross-sectional in } \\
\text { 28,409 French partici- } \\
\text { pants in health screen- } \\
\text { ing (III) }\end{array}$ & $\begin{array}{l}\text { Mean Ccr estimated by } \\
\text { CG formula in current } \\
\text { smokers was sig- } \\
\text { nificantly higher than } \\
\text { those in former and } \\
\text { never smokers adjusted } \\
\text { for age, gender and BMI. } \\
\text { No difference in the age- } \\
\text { related decline of Ccr } \\
\text { among current, former } \\
\text { and never smokers. }\end{array}$ & $\begin{array}{l}\text { B/Ccr was estimated by } \\
\text { CG formula }\end{array}$ \\
\hline Bleyer AJ,et al.(28) & 2000 & $\begin{array}{l}\text { 3-yr follow up in } 4,142 \\
\text { inhabitants in a U.S. } \\
\text { community aged } 65 \\
\left.\text { years or older (II }{ }^{\mathrm{b}}\right)\end{array}$ & $\begin{array}{l}\text { OR for increase in } \\
\text { serum Cr concentra- } \\
\text { tion ( } \geqq 0.3 \mathrm{mg} / \mathrm{dl} \text { ) in } \\
\text { current smoker vs. } \\
\text { never smokers was } 2.10 \\
(1.4 \sim 3.1) \text { adjusted for } \\
\text { age, gender and body } \\
\text { weight. }\end{array}$ & $\begin{array}{l}\text { C/Short period of obser- } \\
\text { vation }\end{array}$ \\
\hline
\end{tabular}


Briganti EM,et al.(12) 2002
Population-based Caseadults in a Australian community (III) control study in 11,247

OR for low eGFR $(<60$ $\mathrm{ml} / \mathrm{min} / 1.73 \mathrm{~m} 2$ ) estimated by CG formula in male current smokers was Ex-smoking was 3.59 (1.27 10.09), but $0.90(0.39 \sim 2.06)$ in female not considered smokers in comparison with nonsmokers adjusted for age, BMI, $\mathrm{BP}$ and FPG.

\begin{tabular}{|c|c|c|}
\hline Haroun MK,et al.(33) & 2003 & $\begin{array}{l}20 \text {-yr follow up in } 23,534 \\
\text { men and women in a } \\
\text { U.S. community }\left(\mathrm{II}^{\mathrm{a}}\right)\end{array}$ \\
\hline Fox CS, et al.(30) & 2004 & $\begin{array}{l}\text { 18.5-yr follow up in 1,223 } \\
\text { men and 1,362 women } \\
\text { in a U.S. community } \\
\left(\mathrm{II}^{\mathrm{a}}\right)\end{array}$ \\
\hline Ejerblad E,et al.(29) & 2004 & $\begin{array}{l}\text { Population-based } \\
\text { case-control study ( } 926 \\
\text { CRF cases) in a Swedish } \\
\text { community (III) }\end{array}$ \\
\hline Baggio B, et al.(27) & 2005 & $\begin{array}{l}\text { 3.6-yr follow up in } 1,283 \\
\text { men and } 1,147 \text { women } \\
\text { in a Italian community } \\
\text { aged } 65-84 \text { years }\left(\mathrm{II}^{\mathrm{a}}\right)\end{array}$ \\
\hline
\end{tabular}

HR for incident ESRD or death due to kidney disease in male and female current smokers vs. nonsmokers was 2.4 (1.5 4.0) and 2.9 (1.7 5.0) respectively adjusted for age, DM and BP.

OR for incident low eGFR $(\leqq 59.25 \mathrm{ml} /$ $\min / 1.73 \mathrm{~m} 2$ in women and $\leqq 64.25 \mathrm{ml} /$ min/1.73 m2in men) was $1.42(1.06 \sim 1.91)$ in current smokers vs. nonsmokers adjusted for age, gender, BMI, DM and hypertension

OR for CRF (serum Cr level $\geqq 3.4 \mathrm{mg} / \mathrm{dl}$ in men and $\geqq 2.8 \mathrm{mg} / \mathrm{dl}$ in women) in smokers consuming 16-30 packyears of cigarettes and in those consuming more vs. never smokers was $1.32(1.00 \sim 1.75)$ and 1.52 (1.08 2.14) respectively adjusted for age, gender, alcohol, education and the use of analgesics.

$\mathrm{OR}$ for increase in serum $\mathrm{Cr}$ concentration ( $\geqq 26.5 \mu$ mole $/ 1$ )was 2.29 (1.00 5.27) in current smokers consuming 20 cigarettes per day or more vs.never smokers adjusted for age, DM, hypertension and high plasma fibrinogen.
C

C/ Not excluding mild CKD patients at the baseline

C/ Ex-smoking was not considered
B/ Renal function was evaluated only by serum $\mathrm{Cr}$ level
B/ Renal function was evaluated only by serum $\mathrm{Cr}$ level 


\begin{tabular}{|c|c|c|c|c|}
\hline Hallan S,et al.(31) & 2006 & $\begin{array}{l}\text { Cross-sectional in } \\
30,485 \text { males and } 34,708 \\
\text { females } 34,708 \text { females } \\
\text { in a Norwegian com- } \\
\text { munity (III) }\end{array}$ & $\begin{array}{l}\text { OR for CKD }(\text { eGFR }<45 \\
\mathrm{ml} / \mathrm{min} / 1.73 \mathrm{~m} 2) \text { in } \\
\text { smokers consuming } \\
25-49 \text { pack-years of } \\
\text { cigarettes and in those } \\
\text { consuming more was } \\
1.42(1.00 \sim 2.00) \text { and } 2.05 \\
(1.08 \sim 3.89) \text { respectively } \\
\text { adjusted for age and } \\
\text { gender. }\end{array}$ & $\begin{array}{l}\text { B/ Not excluding DM } \\
\text { patients }\end{array}$ \\
\hline Shankar A,et al.(37) & 2006 & $\begin{array}{l}\text { 5-yr follow up in 3,392 } \\
\text { inhabitants aged } 43-84 \\
\text { years in a U.S. commu- } \\
\text { nity }\left(\mathrm{II}^{\mathrm{a}}\right)\end{array}$ & $\begin{array}{l}\text { Cross-sectional phase: } \\
\text { OR for CKD (eGFR<60 } \\
\mathrm{ml} / \mathrm{min} / 1.73 \mathrm{~m} 2) \text { in } \\
\text { smokers consuming } \\
15-34 \text { pack-years of } \\
\text { cigarettes and in those } \\
\text { consuming more was } \\
2.57 \text { (1.79 3.70) and } 2.93 \\
(2.08 \sim 4.12) \text { respec- } \\
\text { tively adjusted for age, } \\
\text { gender, BMI, education, } \\
\text { DM and hypertension. } \\
\text { Follow up phase: OR } \\
\text { for incident CKD in } \\
\text { current smokers vs. } \\
\text { never smokers was } 1.97 \\
\text { (1.15 3.36) adjusted for } \\
\text { the confounders. }\end{array}$ & $\begin{array}{l}\text { B/ Not excluding DM } \\
\text { patients }\end{array}$ \\
\hline Yamagata $\mathbf{K}$,et al.(38) & 2007 & $\begin{array}{l}\text { 10-yr follow up in } 41,012 \\
\text { men and } 82,752 \text { women } \\
\text { aged } 40 \text { years or older } \\
\text { in a Japanese commu- } \\
\text { nity }\left(\mathrm{II}^{\mathrm{a}}\right)\end{array}$ & $\begin{array}{l}\text { OR for incidence of } \\
\text { stage } 1 \text { and } 2 \text { CKD in } \\
\text { current smokers was } \\
1.26(1.14 \sim 1.41) \text { in men } \\
\text { and } 1.40(1.16 \sim 1.69) \\
\text { in women adjusted } \\
\text { for age, obesity,DM, } \\
\text { hypertension, hyperlip- } \\
\text { idemia and alcohol. OR } \\
\text { for incidence of stage } 3 \\
\text { CKD in current smokers } \\
\text { was } 1.13 \text { (1.05 1.22) in } \\
\text { men and } 1.16 \text { (1.06 1.26) } \\
\text { in women adjusted for } \\
\text { the confounders. }\end{array}$ & $\begin{array}{l}\text { B/ Not excluding DM } \\
\text { patients }\end{array}$ \\
\hline Noborisaka Y,et al.(36) & 2007 & $\begin{array}{l}\text { Cross-sectional in 2,133 } \\
\text { male Japanese workers } \\
\text { (III) }\end{array}$ & $\begin{array}{l}\text { Mean Ccr estimated } \\
\text { by CG formula was } \\
\text { significantly higher in } \\
\text { current smokers than } \\
\text { in former and never } \\
\text { smokers adjusted for } \\
\text { age and BMI. }\end{array}$ & $\begin{array}{l}\text { C/Ccr was estimated by } \\
\text { CG formula }\end{array}$ \\
\hline Zhang L,et al.(26) & 2008 & $\begin{array}{l}\text { Cross-sectional in 13,925 } \\
\text { adults in communities } \\
\text { in China (III) }\end{array}$ & $\begin{array}{l}\text { OR for low eGFR }(<60 \\
\mathrm{ml} / \mathrm{min} / 1.73 \mathrm{~m} 2) \text { was } \\
1.15(0.79 \sim 1.68) \text { in } \\
\text { current smokers vs. } \\
\text { non-smokers adjusted } \\
\text { for age, gender, obesity, } \\
\text { DM, hypertension and } \\
\text { hyperlipidemia. }\end{array}$ & $\begin{array}{l}\text { B/ Ex-smoking was not } \\
\text { considered }\end{array}$ \\
\hline
\end{tabular}


Kronborg J,et al .(34) 2008

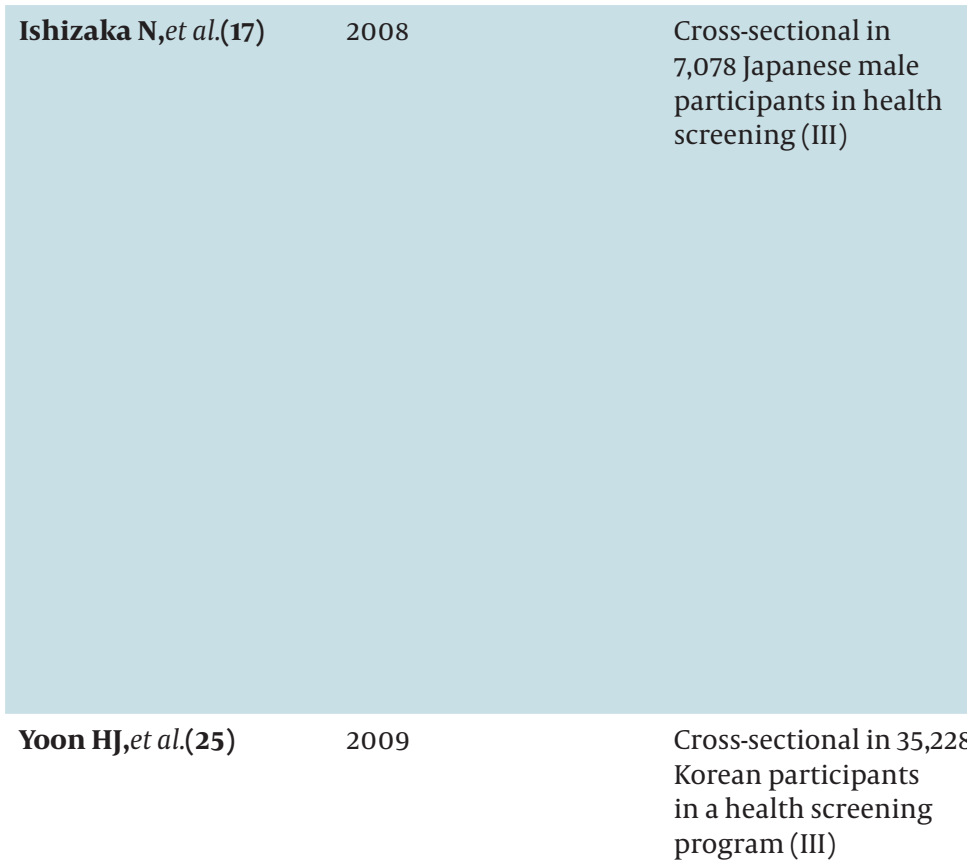

Sauriasari R,et al.(22) 2010 7-yr follow up in 2,249 men and 2,192 women in a Norwegian community $\left(\mathrm{II}^{\mathrm{a}}\right)$
Current female smokers showed a signifcantly larger increase in eGFR during 7 years as compared with never smokers adjusted for age, WC,BP, DM, alcohol and physical activity, while male smokers did not.

OR for low eGFR $(<60$ $\mathrm{ml} / \mathrm{min} / 1.73 \mathrm{~m} 2)$ in current smokers consuming 20-39 cigarettes per day and those consuming more was $0.63(0.49 \sim 0.83)$ and $0.32(0.13 \sim 0.79)$ respectively adjusted for age, SBP and FPG. OR for high eGFR $(>90.73$ $\mathrm{ml} / \mathrm{min} / 1.73 \mathrm{~m} 2$ ) current smokers consuming 20-39 cigarettes per day and those consuming more was 2.35

(1.56 3.54) and 2.46 (1.01 6.00) respectively adjusted for the confounders.

Cross-sectional in 290 male and 359 female Japanese participants in in smokers consuming health screening (III)
B/ Not excluding DM patients

B/ Not excluding DM patients
Mean eGFR was significantly higher in current smokers than in former and never smokers. In the subjects showing a low eGFR $(<50 \mathrm{ml} /$ $\min / 1.73 \mathrm{~m} 2)$, current smokers showed lower eGFR than former and never smokers. OR for incident low eGFR (<60 ml/min/1.73 m2) in current smokers consuming up to 20 cigarettes and in those consuming more was $0.76(0.62 \sim 0.94)$ and $0.73(0.60 \sim 0.90)$ respectively adjusted for age, BMI, BP and FPG.

OR for high eGFR ( $\geqq 96.7 \mathrm{ml} / \mathrm{min} / 1.73 \mathrm{~m} 2$ )

A less than 20 pack-years and in those consuming more vs. never smokers was $1.08(0.59 \sim 1.98)$ and 2.38 (1.15 4.93) respectively adjusted for age, gender, BMI and BP. 


\begin{tabular}{|c|c|c|c|c|}
\hline Miyatake $\mathbf{N}$,et al.(35) & 2010 & $\begin{array}{l}\text { 5-yr follow up in } 286 \\
\text { male Japanese workers } \\
\left(\mathrm{II}^{\mathrm{a}}\right)\end{array}$ & $\begin{array}{l}\text { Reduction of eGFR } \\
\text { during } 5 \text { years was sig- } \\
\text { nifcantly smaller in } 145 \\
\text { current smokers than } \\
\text { in } 141 \text { nonsmokers. }\end{array}$ & $\begin{array}{l}\text { C/ Small number of } \\
\text { subjects }\end{array}$ \\
\hline Hallan SI, Orth SR (32) & 2011 & $\begin{array}{l}\text { 10-yr (median) follow } \\
\text { up in } 65,589 \text { adults } \\
\text { from a community in } \\
\text { Norway }\left(\mathrm{II}^{\mathrm{a}}\right)\end{array}$ & $\begin{array}{l}\text { HR for the incidence of } \\
\text { stage } 5 \text { CKD in former } \\
\text { and current male smok- } \\
\text { ers was 3.74(1.05 13.2) } \\
\text { and 5.75(1.46 22.6), } \\
\text { respectively, as com- } \\
\text { pared to never-smokers. } \\
\text { HR was 3.19(0.76 13.5) } \\
\text { and } 2.77(0.64 \sim 11.9) \text {, } \\
\text { respectively, in females. } \\
\text { Cessation of smoking } \\
\text { significantly reduced } \\
\text { the incidence of stage } 5 \\
\text { CKD dependently to the } \\
\text { lapsed years from the } \\
\text { cessation. }\end{array}$ & $\begin{array}{l}\mathrm{C} / \text { Not excluding mild } \\
\text { CKD patients at the } \\
\text { baseline }\end{array}$ \\
\hline Noborisaka Y, et al.(7) & 2011 & $\begin{array}{l}\text { Cross-sectional in } 990 \\
\text { middle-aged Japanese } \\
\text { men from a chemical } \\
\text { plant (III) }\end{array}$ & $\begin{array}{l}\text { Mean eGFR was sig- } \\
\text { nificantly higher in } \\
\text { current smokers than } \\
\text { in former and never } \\
\text { smokers. Normal but } \\
\text { high eGFR ( } \geqq 110 \mathrm{ml} / \\
\text { min/1.73 m2) was } 6.7 \% \text { in } \\
\text { current heavy smokers } \\
\text { and subnormal eGFR (< } \\
60 \mathrm{ml} / \mathrm{min} / 1.73 \mathrm{~m} 2 \text { ) was } \\
5.7 \% \text { in those with a BI } \\
\text { of } 600 \text { or higher while } \\
\text { both were } 3.0 \% \text { or less } \\
\text { in never-smokers, al- } \\
\text { though the differences } \\
\text { between smokers and } \\
\text { non-smokers were not } \\
\text { significant. }\end{array}$ & A \\
\hline
\end{tabular}

Abbreviations: BI, Brinkman Index; BP, blood pressure; BMI, body mass index; Ccr, creatinine clearance; CG formula, Cockcroft and Gault formula; Cr, creatinine; DM, diabetes mellitus; ESRD, end stage renal disease; FPG, fasting plasma glucose; HR: hazard ratio, LOE, level of evidence defined by AHCPR (1993), OR: odds ratio

${ }^{a}$ Quality: For the definition, refer to text and Table 1.

${ }^{\mathrm{b}}$ Comment: The main reason for grading the article as $\mathrm{B}$ or $\mathrm{C}$.

ity $(27,29,31,37,38)$ detected a significant effect of smoking on the decline of renal function, which was also suggested in other 6 studies with grade C $(12,26,28,30$, $32,33)$. These studies were all conducted in community populations, some of those included many elderly persons $(27,28,37,38)$ or CKD patients $(32,33)$. Yamagata et al. (38) followed 124,000 inhabitants aged 40 years or older in a community in Japan for 10 years, excluding all those showing CKD signs beforehand, and observed that smoking caused a significant but only $10 \%$ increase in the risk for a declining GFR to the level of less than $60 \mathrm{ml} /$ $\mathrm{min} / 1.73 \mathrm{~m}$. On the other hand, 9 studies with any grade in quality even showed a higher GFR or Ccr in smokers than in non-smokers, especially those conducted in working populations $(7,17,22,25,35,36)$. A significantly lower risk of a low GFR was even observed in current smokers (17,
25). No difference was observed in age-related decline of GFR or Ccr among current and former smokers, and lifetime non-smokers $(7,15)$. One study showed even a more modest decline of GFR in smokers than in non-smokers during a 5-year period (35)

In addition to the generally low LOE and quality of the literature, this article has some other limitations. The literature was collected only from the MEDLINE database, and some important articles may thus have been overlooked. The methods and manner of quality evaluation of the articles in this review have not been approved by experts other than us, which might have added some arbitrariness to the evaluation. But, in these specific circumstances, this review reveals some peculiar paradoxical findings of CKD signs in smokers in healthy populations, i.e., a persistently high appearance of proteinuria 
often accompanied with an elevated GFR.

\section{Discussion}

\subsection{Significance of the Paradoxical CKD Signs in Smokers}

Yoon et al. (25) in Korea has already pointed out the paradoxical CKD signs in a cross-sectional observation in 35,288 participants of a health screening program, and named "the different effect of smoking on GFR and proteinuria in a healthy population". They mentioned that the association of smoking status with GFR was different between those showing a GFR of $50 \mathrm{ml} / \mathrm{min} / 1.73 \mathrm{~m}^{2}$ or above and those with a lower GFR. In those with the relatively high GFR, smokers showed a higher mean GFR than non-smokers, but an inverse association was observed in those with the low GFR, i.e., smokers have a lower GFR than non-smokers. From these findings and the limited appearance of proteinuria even in smokers, Yoon et al. proposed a hypothesis that most smokers from the general population do not show deteriorations of renal function even though they showed an elevated GFR, while only a small, especially susceptible subset of the population would show a lowered GFR and proteinuria. However, this hypothesis has not yet been confirmed.

Possible factors underlying the development of CKD in smokers were extensively discussed by Orth and Hallan (2) such as hypoxia, heavy metals in tobacco smoke, intrarenal vasoconstriction, oxidative stress and inflammatory process. Although the exact variable has remained uncertain, the intraglomerular hypertension caused by the intrarenal hemodynamic changes due to nicotine in cigarette smoke may be the most plausible reason. The high GFR in smokers may thus be a reflection of glomerular hyperfiltration following the intraglomerular hypertension and the early sign of renal damage like that observed in the early stage of diabetic nephropathy (39). If so, the high GFR in smokers may eventually decrease to a low level with continued smoking and cause proteinuria. However, this has not been confirmed either since longitudinal observations on GFR have so far failed to identify a more marked decline of GFR in smokers than in nonsmokers $(34,35)$.

\subsection{Advantages of Studies in Workplaces}

The number of CKD patients is estimated to be 13 million or more in Japan, which is more than $10 \%$ of the national population. However, it has not been well recognized among healthcare experts, especially those engaged in preventing activities for life-style diseases at worksites. The population of Japan is aging rapidly and so is the workforce, and most workplaces are predicted to have as many as 30\% or more workers aged 60 years or older in 2050. Since the renal toxic effects of smoking are more predominant in elderly persons, healthcare experts at worksites may face the far-ranging and profound impact of smoking-induced CKD in the near future.

The aging of the working population, on the other hand, may provide healthcare experts at worksites with a greater chance of observing the long-term annual changes in renal function in smokers throughout middle-age to the age of 70 years or longer. Therefore, workplaces may have special merits of revealing a more conspicuous decline of GFR in smokers once showing a higher GFR as compared to non-smokers from the data collected by the annual health check-ups mandated by the workplace. Healthcare experts at workplaces should pay more attention to smoking-induced CKD.

\section{Acknowledgements}

I am very grateful for the support and advice provided by Prof. Yuichi Yamada, Department of Social and Environmental Medicine, Kanazawa Medical University School of Medicine Ishikawa, Japan.

\section{Authors' Contributions}

Yuka Noborisaka is the only author of the article.

\section{Financial Disclosure}

No finamcial support by any institution.

\section{Funding/Support}

This article is supported financially by KAKENHI, a Grant-in-Aid for Scientific Research (C), 2010, from the Japan Society for the Promotion of Science (JSPS).

\section{References}

1. Orth SR. Effects of smoking on systemic and intrarenal hemodynamics: influence on renal function. J Am Soc Nephrol. 2004;15(Suppl 1):S58-63.

2. Orth SR, Hallan SI. Smoking: a risk factor for progression of chronic kidney disease and for cardiovascular morbidity and mortality in renal patients-absence of evidence or evidence of absence? Clin J Am Soc Nephrol. 2008;3(1):226-36.

3. Orth SR, Ritz E. The renal risks of smoking: an update. Curr Opin Nephrol Hypertens. 2002;11(5):483-8.

4. Orth SR, Ritz E, Schrier RW. The renal risks of smoking. Kidney Int 1997;51(6):1669-77.

5. Janssen WM, Hillege H, Pinto-Sietsma SJ, Bak AA, De Zeeuw D, de Jong PE. Low levels of urinary albumin excretion are associated with cardiovascular risk factors in the general population. Clin Chem Lab Med. 2000;38(11):1107-10.

6. Jones-Burton C, Seliger SL, Scherer RW, Mishra SI, Vessal G, Brown J, et al. Cigarette smoking and incident chronic kidney disease: a systematic review. Am J Nephrol. 2007;27(4):342-51.

7. Noborisaka Y, Ishizaki M, Nakata M, Yamada Y, Honda R, Yokoya$\mathrm{ma} \mathrm{H}$, et al. Cigarette smoking, proteinuria, and renal function in middle-aged Japanese men from an occupational population. Environ Health Prev Med. 2012;17(2):147-56.

8. Cho MK, Bero LA. Instruments for assessing the quality of drug studies published in the medical literature.JAMA.1994;272(2):1014.

9. Harris RP, Helfand M, Woolf SH, Lohr KN, Mulrow CD, Teutsch SM, 
et al. Current methods of the US Preventive Services Task Force: a review of the process. Am J Prev Med. 2001;20(3 Suppl):21-35.

10. Levey AS, Bosch JP, Lewis JB, Greene T, Rogers N, Roth D. A more accurate method to estimate glomerular filtration rate from serum creatinine: a new prediction equation. Modification of Diet in Renal Disease Study Group. Ann Intern Med.1999;130(6):461-70.

11. Cockcroft DW, Gault MH. Prediction of creatinine clearance from serum creatinine. Nephron. 1976;16(1):31-41.

12. Briganti EM, Branley P, Chadban SJ, Shaw JE, McNeil JJ, Welborn TA, et al. Smoking is associated with renal impairment and proteinuria in the normal population: the AusDiab kidney study. Australian Diabetes, Obesity and Lifestyle Study. Am J Kidney Dis. 2002;40(4):704-12.

13. Cirillo M, Senigalliesi L, Laurenzi M, Alfieri R, Stamler J, Stamler $\mathrm{R}$, et al. Microalbuminuria in nondiabetic adults: relation of blood pressure, body mass index, plasma cholesterol levels, and smoking: The Gubbio Population Study. Arch Intern Med. 1998;158(17):1933-9.

14. Goetz FC, Jacobs DR, Jr., Chavers B, Roel J, Yelle M, Sprafka JM. Risk factors for kidney damage in the adult population of Wadena, Minnesota. A prospective study. Am J Epidemiol. 1997;145(2):91102.

15. Halimi JM, Giraudeau B, Vol S, Caces E, Nivet H, Lebranchu Y, et al. Effects of current smoking and smoking discontinuation on renal function and proteinuria in the general population. Kidney Int. 2000;58(3):1285-92.

16. Hogan SL, Vupputuri S, Guo X, Cai J, Colindres RE, Heiss G, et al. Association of cigarette smoking with albuminuria in the United States: the third National Health and Nutrition Examination Survey. Ren Fail. 2007;29(2):133-42.

17. Ishizaka N, Ishizaka Y, Toda E, Shimomura H, Koike K, Seki G, et al. Association between cigarette smoking and chronic kidney disease in Japanese men. Hypertens Res. 2008;31(3):485-92.

18. Krol E, Rutkowski B, Czarniak P, Kraszewska E. Aging or comorbid conditions - what is the main cause of kidney damage? J Nephrol. 2010;23(4):444-52.

19. Metcalf PA, Baker JR, Scragg RK, Dryson E, Scott AJ, Wild CJ. Albuminuria in people at least 40 years old: effect of alcohol consumption, regular exercise, and cigarette smoking. Clin Chem. 1993;39(9):1793-7.

20. O'Seaghdha CM, Hwang SJ, Upadhyay A, Meigs JB, Fox CS. Predictors of incident albuminuria in the Framingham Offspring cohort. Am J Kidney Dis. 2010;56(5):852-60.

21. Pinto-Sietsma SJ, Mulder J, Janssen WM, Hillege HL, de Zeeuw D, de Jong PE. Smoking is related to albuminuria and abnormal renal function in nondiabetic persons. Ann Intern Med. 2000;133(8):585-91.

22. Sauriasari R, Sakano N, Wang DH, Takaki J, Takemoto K, Wang B, et al. C-reactive protein is associated with cigarette smoking-induced hyperfiltration and proteinuria in an apparently healthy population. Hypertens Res. 2010;33(11):1129-36.

23. Tozawa M, Iseki K, Iseki C, Oshiro S, Ikemiya Y, Takishita S. Influence of smoking and obesity on the development of proteinuria. Kidney Int. 2002;62(3):956-62.

24. Yamada Y, Noborisaka Y, Ishizaki M, Honda R, Tsuritani I, Yamada S. Association between cigarette consumption and proteinuria in healthy Japanese men and women from an occupational population. J Occup Health. 2004;46(5):365-73.

25. Yoon HJ, Park M, Yoon H, Son KY, Cho B, Kim S. The differential effect of cigarette smoking on glomerular filtration rate and proteinuria in an apparently healthy population. Hypertens Res. 2009;32(3):214-9.

26. Zhang L, Zhang P, Wang F, Zuo L, Zhou Y, Shi Y, et al. Prevalence and factors associated with CKD: a population study from Beijing. Am J Kidney Dis. 2008;51(3):373-84.

27. Baggio B, Budakovic A, Perissinotto E, Maggi S, Cantaro S, Enzi $\mathrm{G}$, et al. Atherosclerotic risk factors and renal function in the elderly: the role of hyperfibrinogenaemia and smoking. Results from the Italian Longitudinal Study on Ageing (ILSA). Nephrol Dial Transplant. 2005;20(1):114-23.

28. Bleyer AJ, Shemanski LR, Burke GL, Hansen KJ, Appel RG. Tobacco, hypertension, and vascular disease: risk factors for renal functional decline in an older population. Kidney Int. 2000;57(5):20729.

29. Ejerblad E, Fored CM, Lindblad P, Fryzek J, Dickman PW, Elinder CG, et al. Association between smoking and chronic renal failure in a nationwide population-based case-control study. J Am Soc Nephrol. 2004;15(8):2178-85.

30. Fox CS, Larson MG, Leip EP, Culleton B, Wilson PW, Levy D. Predictors of new-onset kidney disease in a community-based population. JAMA. 2004;291(7):844-50.

31. Hallan S, de Mutsert R, Carlsen S, Dekker FW, Aasarod K, Holmen J. Obesity, smoking, and physical inactivity as risk factors for CKD: are men more vulnerable? Am J Kidney Dis. 2006;47(3):396-405.

32. Hallan SI, Orth SR. Smoking is a risk factor in the progression to kidney failure. Kidney Int. 2011;80(5):516-23.

33. Haroun MK, Jaar BG, Hoffman SC, Comstock GW, Klag MJ, Coresh J. Risk factors for chronic kidney disease: a prospective study of 23,534 men and women in Washington County, Maryland. J Am Soc Nephrol. 2003;14(11):2934-41.

34. Kronborg J, Solbu M, Njolstad I, Toft I, Eriksen BO, Jenssen T. Predictors of change in estimated GFR: a population-based 7-year follow-up from the Tromso study. Nephrol Dial Transplant. 2008;23(9):2818-26.

35. Miyatake N, Moriyasu H, Sakano N, Tada S, Suzue T, Hirao T. Influence of cigarette smoking on estimated glomerular filtration rate (eGFR) in Japanese male workers. Acta Med Okayama. 2010;64(6):385-90.

36. Noborisaka Y, Honda R, Ishizaki M, Nakata M, Yamada Y. Alcohol and cigarette consumption, renal function and blood pressure in middle-aged healthy men. J Hum Hypertens. 2007;21(12):966-8.

37. Shankar A, Klein R, Klein BE. The association among smoking, heavy drinking, and chronic kidney disease. Am J Epidemiol. 2006;164(3):263-71.

38. Yamagata K, Ishida K, Sairenchi T, Takahashi H, Ohba S, Shiigai $\mathrm{T}$, et al. Risk factors for chronic kidney disease in a community-based population: a 10-year follow-up study. Kidney Int. 2007;71(2):159-66

39. Mogensen CE. Prediction of clinical diabetic nephropathy in IDDM patients. Alternatives to microalbuminuria? Diabetes. 1990;39(7):761-7. 